\title{
Successful outcome in preeclamptic rudimentary horn pregnancy
}

\author{
Preeklamptik rudimenter boynuz gebeliğinde başanlı sonuç \\ Ruchi Sinha, Shikha Sachan, Anuradha Khanna \\ Department of Obstetrics and Gynecology, Institute of Medical Sciences, Bhu, India
}

\section{Abstract}

Unicornuate uterus with rudimentary horn is an uncommon type of mullerian duct malformation associated with various gynecological and obstetrical complications. Rudimentary horn pregnancy is a rare entity and the majority have rupture of gravid horn leading to maternal and fetal morbidity and mortality. A case of rudimentary horn pregnancy at 32 weeks and 6days with pregnancy induced hypertension is reported where proper management results in successful pregnancy outcome. (J Turkish-German Gynecol Assoc 2011; 12: 53-5)

Key words: Rudimentary horn, unicornuate uterus, pregnancy, preeclampsia

Received: 5 April, 2010

Accepted: 7 June, 2010

\section{Ozet}

Rudimenter boynuzlu unikornuat uterus, çeşitli jinekolojik ve obstetrik komplikasyonlarla ilisskili olan nadir bir müller kanal malformasyonudur. Rudimenter boynuz gebeliği nadir bir durumdur ve çoğunluğunda gebe boynuz rüptüre olarak maternal ve fetal morbidite ve mortaliteye neden olmaktadır. Uygun tedavinin gebeliğin başarılı şekilde sonuçlanmasını sağladığı 32 hafta ve 6 günlük rudimenter boynuz gebeliği ile gebeliğin neden olduğu hipertansiyonu olan bir olgu bildirilmektedir. (J Turkish-German Gynecol Assoc 2011; 12: 53-5)

Anahtar kelimeler: Rudimenter boynuz, Unikornuat uterus, Gebelik, Preeklampsi

Geliş Tarihi: 05 Nisan 2010

Kabul Tarihi: 07 Haziran 2010

Obstetrical examination revealed a fundal height corresponding to 32 weeks of gestation and deviation of the uterus to the right. The fetus was cephalic and fetal heart rate was $114 \mathrm{bpm}$. Cardiotocography was carried out and was nonreactive. Her hemoglobin was $12.5 \mathrm{gm} / \mathrm{dl}$, urine albumin $2+$, uric acid $7.2 \mathrm{mg} / \mathrm{dl}$, creatinine $1.0 \mathrm{mg} / \mathrm{dl}$ and random blood sugar $69.0 \mathrm{mg} / \mathrm{dl}$. Her liver function tests and renal function tests were normal. The ultrasonography (USG) of the second trimester done at the periphery was reported to be normal. Repeat USG with a biophysical profile (BPP) was done which revealed a 4/10 score with an amniotic fluid index of 8 . The patient was moved for emergency caesarean section in view of low BPP (fetal distress). On laparotomy pregnancy was located in the right horn of uterus and the left horn was approximately 6 weeks size. The right horn was extensively fused to the left. The left and right fallopian tubes and ovaries were attached to the respective horns (Figure 1). Low transverse incision was made over the right horn and the baby was delivered. Placenta was delivered by control cord traction. Placenta and membranes were normal on gross examination. Clamps were applied and the right horn excised along with right salpingectomy (Figure 2). Both ovaries were preserved. The baby was a $1560 \mathrm{gm}$ female with an Apgar score of $8 / 10$ and $9 / 10$ at $1 \mathrm{~min}$ and 5 min respectively.

The patient made an uneventful recovery and was discharged home on the tenth day. The follow up at 6 weeks was normal. 


\section{Discussion}

Mullerian duct anomalies are infrequently encountered in day to day gynecological practice. The incidence of mullerian duct malformation in the general population is estimated to be $4.3 \%$ (3). The unicornuate uterus with a rudimentary horn is a rare type of mullerian duct malformation and results from the defective fusion of the malformed duct with the contra-lateral duct, the incidence being $0.4 \%$ (3). In $80-90 \%$ of the cases rudimentary horn is not connected to the uterine cavity (4).

Rudimentary horn pregnancy (RHP) is a very rare entity. Conception occurs in the rudimentary horn due to transperitoneal migration of sperm or zygote, although a corpus luteum has been observed on the contralateral side in only $10 \%$ of the cases (5). Rudimentary horn pregnancy has a very poor maternal and fetal outcome. The most common and life threatening complication of rudimentary horn pregnancy is rupture (80\%). The rupture usually occurs in the first and second trimester (80\%) and infrequently in the third trimester (20\%) (6). Rupture leads to torrential intraperitoneal bleeding with severe maternal and fetal mortality. Here lies the importance of prerupture diagnosis but the prerupture diagnosis is extremely difficult. Literature shows a preclinical detection rate of $8 \%$ and a preoperative detection rate of $29 \%$ only (7). The diagnosis is possible only with a high index of clinical suspicion and radiological investigations (USG \& MRI) $(7,8)$. The bimanual finding of palpable mass extending outward from the uterine angle (Baart de la faille's sign) or displacement of the fundus to the contralateral side with rotation of the uterus and elevation of the affected horn (Ruge Simon Syndrome) or deviation of the uterus to one side with an adnexal mass in pregnancy should arouse suspicion of a rudimentary horn. USG in early trimesters are helpful in diagnosing a case of RHP. Tsafrir et al. suggested the following criteria for early sonographic diagnosis of rudimentary horn pregnancy (8). (i) a pseudo pattern of an asymmetrical bicornuate uterus, (ii) absent visual continuity in tissue surrounding the gestational sac and the uterine cervix and (iii) the presence of myometrial tissue surrounding the gestational sac. Additionally, MRI can be used to confirm the diagnosis before laparatomy is undertaken. Buntugu et al have also shown that in low resource centres, placement of a Foley catheter into the uterine cavity and performing a transabdominal ultrasound scan can conclusively exclude an intact uterine pregnancy (9).

In addition to rupture, the RHP usually lead to missed abortion or intrauterine death; and rarely, fetal survival has been reported. Until 1999, only 13 neonatal survivals were reported in the English Literature (10). In an exhaustive review of $20^{\text {th }}$ century literature, Nahum reported only $6 \%$ of RHP which have progressed to term, with a $13 \%$ neonatal survival (6). Goel et al. have reported a case of post dated RHP but the baby could not survive following delivery (11).

Ours is a case of RHP referred to our hospital in the third trimester with successful fetal and maternal survival. The preoperative diagnosis was not possible in our case, as the early pregnancy USG was done at a peripheral hospital where there was no expertise and it is difficult to diagnose RHP in cases of late trimester USG.

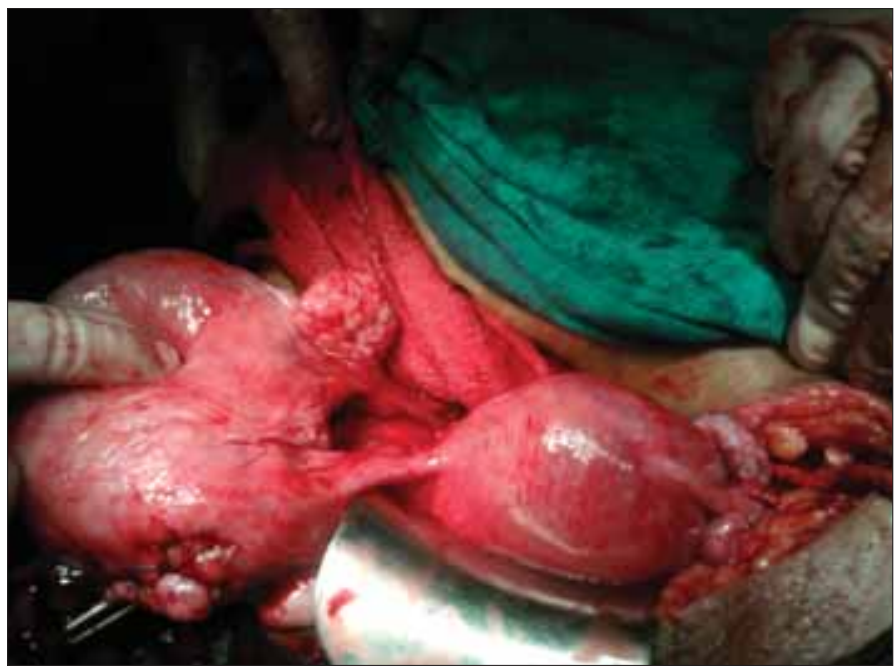

Figure 1. Unicornuate uterus and rudimentary horn

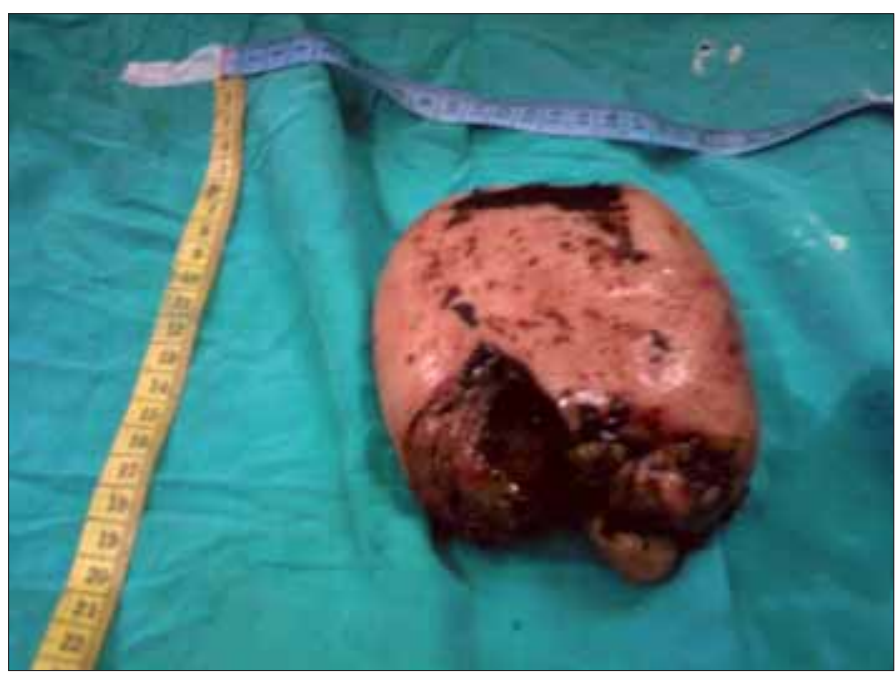

Figure 2. Excised rudimentary horn

The endometrium of the rudimentary horn has been described as thinner than usual and sometimes even non functional (12). Pathological placentation may lead to placenta accrete, as reported in various cases $(13,14)$. It is also possible that poor placentation in horn pregnancy may be a cause of preeclampsia and fetal distress or low BPP in our case.

The management of RHP is laparotomy and surgical excision of the rudimentary horn and tube, as was done in our case. In the literature, the laparoscopic removal of pre and post rupture RHP is reported but this is carried out in cases of early diagnosis $(6,15)$.

\section{Conclusion}

RHP is an extremely rare entity. The high index of suspicion is important to diagnose it early i.e. before rupture, to prevent life threatening consequences. A timely and proper management can result in a successful pregnancy outcome even in horn pregnancy. 


\begin{abstract}
Abbreviations
PIH: Pregnancy induced hypertension, BPP: Biophysical profile, USG: Ultrasonography, RHP: Rudimentary horn pregnancy
\end{abstract}

\section{Consent}

Written informed consent was taken from the patient for the publication of this case report and any accompanying images. A copy of the written consent is available for the review of the Editor in Chief of this journal.

\section{Conflict of interest}

No conflict of interest is declared by authors.

\section{References}

1. Johansen K. Pregnancy in a rudimentary horn: two case reports. Obstet Gynecol 1969; 34: 805-8.

2. Nahum GG. Rudimentary uterine horn pregnancy: a case report on surviving twins delivered eight days apart. J Reprod Med 1997; 42: 525-53

3. Grimbizis GF, Camus M, Tarlatzis BC, Bontis JN, Devroey P. Clinical implications of uterine malformations and hysteroscopic treatment results. Hum Reprod Update 2001; 7: 161-74. [CrossRef]

4. Liu MM. Unicornuate uterus with rudimentary horn. Int J Gynecol Obstet 1994; 44: 149-53. [CrossRef]

5. O'Leary JL, O'Leary JA. Rudimentary horn pregnancy. Obstet Gynecol 1963; 22: 371-5.
6. Nahum GG. Rudiemtnary uterine horn pregnancy: The 20th century worldwide experience of 588 cases. J Reprod Med 2002; 47: 151-63.

7. Jayasinghe Y, Rane A, Stalewksi H, Grover S. The presentation and early diagnosis of the rudimentary uterine horn. Obstet Gynecol 2005; 105: 1456-67. [CrossRef]

8. Tsafrir A, Rojansky N, Sela HY, Gomori JM, Nadjari M. Rudimentary horn pregnancy: First-trimester prerupture sonographic diagnosis and confirmation by magnetic resonance imaging. J Ultrasound Med 2005; 24: 219-23.

9. Buntugu K, Ntumy M, Ameh E, Obed S. Rudimentary horn pregnancy: Pre-rupture diagnosis and management. Ghana Medical Journal 2008; 42: 92-4.

10. McCarthy E. A case report and review of pregnancies in rudimentary non-communicating uterine horns. Aust NZ J Obstet Gynaecol 1999; 39:188-90.

11. Goel P, Saha PK, Mehra R, Huria A. Unruptured postdated pregnancy with a live fetus in a non communicating rudimentary horn, Indian J of Med Sci, 2007; 61: 23-7. [CrossRef]

12. Fedele L, Marchini M, Baglioni A, Carinelli S, Zamberletti D, Candiani GB. Endometrium of cavitary rudimentary horns in unicornuate uteri. Obstet Gynecol 1990; 75: 437-40.

13. Basbug M, Soyller I, Aygen E. Placenta accreta associ-ated with rupture of a rudimentary horn pregnancy Int J Gynaecol Obstet 1997; 57: 199-201. [CrossRef]

14. Oral B, Guney M, Ozsoy M, Sonal S. Placenta accreta associated with a ruptured pregnant rudimentary uterine horn: case report and review of the literature. Arch Gynecol Obstet 2001; 265: 100-2 [CrossRef]

15. Yoo EH, Chun SH, Woo BH. Laparoscopic resection of a rudimentary horn pregnancy. Acta Obstet Gynecol Scand 1999; 78: 167-8. 